\title{
Learning and teaching natural science in the early years: A case study of three different contexts
}

\begin{abstract}
Currently many children in early childhood education cannot be accommodated in provincial department schools. Consequently, different non-governmental institutions offer Grade R programmes in an attempt to support the DBE. Pre-primary schools that traditionally took responsibility for early childhood education also offer Grade $R$ education. The recent policy decision to include Grade $\mathrm{R}$ in the primary school is an innovation, which is still in its infancy. It is against this background that the national South African Curriculum (NCS) has to be implemented. This paper focuses on the teaching of natural science in Grade $\mathrm{R}$ and attempts to determine if the teaching and learning of natural science has different outcomes in the different contexts described above. An oral questionnaire was administered to capture children's understanding of natural science phenomena, while interviews provided data with regard to teachers' understanding of natural science in the foundation phase. The results show that there are differences in children's understanding of natural phenomena in the different contexts and these differences are related to teachers' understanding of the curriculum, as well as their views of the nature of science.
\end{abstract}

Keywords: Grade R; science teaching; process skills; teachers' understanding of science.

Angela James, School of Education, University of KwaZulu-Natal. E-mail: jamesa1@ukzn. ac.za. Michèle Stears, School of Education, University of KwaZulu-Natal. E-mail: stearsm@ ukzn.ac.za. Claire Moolman, School of Education, University of KwaZulu-Natal. E-mail: claireybelle87@gmail.com. 


\section{Introduction}

Early Childhood Development (ECD) is a broad term that includes reference to the policies and practices that focus on the development of children from birth to nine years of age. According to an earlier document from the Department of Education, White Paper Five, the Education and Training Policy document (2001: 9) -

... early childhood development is an umbrella term that applies to the processes by which children from birth to at least nine years grow and thrive, physically, mentally, emotionally, spiritually, morally and socially.

The development of young children is viewed in a holistic manner in that all the human facets are considered, but rather counter intuitively, the cognitive development of children is not viewed as primary. The influences of all the aspects on the development of a child are given a primary view.

In many countries the provision of primary education during the early years is recognised as a right for all citizens. The World Declaration on the Survival, Protection and Development of Children, agreed to by many nations at the World Summit of Children in 1990, focused on the rights of children "to give every child a better future" (United Nations Committee on Education, 1990: 1). The early years for children are critical for their development later on in life. According to the White Paper Five policy document -

With quality ECD provision in South Africa, educational efficiency would improve as children would acquire the basic concepts, skills and attitudes required for successful learning and development (White Paper Five, 2001: 8).

Essentially, all the above-mentioned policies were concerned with an integrated approach to the cognitive, social, emotional and psycho-social development of children (Education White Paper, 2001).

In South Africa the Bill of Rights in our Constitution, Act 108, Section 29 (1)(a), (Republic of South Africa, 1996) stipulates that -

... everyone has the right to a basic education, including adult basic education; and further education, which the State, through reasonable measures, must make progressively available and accessible.

These policies are significant in bringing attention to the importance of education for all citizens, especially young children. A further requirement that all young children should have access to education of equal quality has encountered many challenges. Further challenges are highlighted in the "Education for All" policy document (Department of Basic Education, 2010), in that, the early childhood development phase crosses a number of different departments, as there are various aspects that need to be considered, such as the welfare of children and the health of children. However, the role of the national Department of Education (DoE) cannot be ignored or subsumed. It has the responsibility of increasing access to education for young children, especially those from rural areas, by establishing appropriate ECD sites (DoE, 2006). 
Currently, many facilities that cater for children in the pre-formal schooling phase (including Grade R) are run by non-governmental agencies. While the intention of the department of education, in the early post 1994 years, may have been to bring all such facilities under its control, this was not feasible. According to Biersteker (2010: 13), "the primary site of intervention is the home and a range of programmes will be needed to reach all children especially the majority who are poor and vulnerable". What we have today, as a result, are many centre-based (formal) services that serve about 20\% of the children younger than five years (Biersteker, 2010: 15). Certain facilities are not formally part of the DoE, but are subsidised by it, while others receive no such support. Such subsidies are usually inadequate and these facilities depend on the community for additional funding. This, of course, perpetuates inequities of the past as poor communities are less able to provide adequate finances and children from such communities lack the necessary facilities required to prepare them for formal schooling. KwaZulu-Natal, with its high population, has many such facilities which are often referred to as 'crèches'. As it is the policy of the DBE that Grade R should be part of the foundation phase, schools are increasingly offering it as part of their foundation phase programme, effectively creating a new sector for Grade R teaching. A number of pre-schools that existed prior to 1994 still exist and offer programmes exclusively for three to six year olds. These schools are funded by parents but with limited support from the state and thus exclude children from low-income homes.

In South Africa every facility that offers Grade $\mathrm{R}$ is expected to adopt and implement early childhood programmes that focus on the holistic development of young children. Within this programme the cognitive, social and emotional development of children is essential. However, the second wave of curriculum renewal (DoE, 2003) was the document that formalised learning within three learning programmes of which life skills is one. Conezio and French (2002: 12) are of the view that allowing children to engage with scientific phenomena is an important part of the curriculum at such a young age (two to five years), as it is the children's "natural interests in science that can be the foundation for developing necessary schooling skills". We shall, however, confine our study to the age group defined as belonging to Grade $\mathrm{R}$ as this grade is considered as being part of the foundation phase and is covered in the RNCS, which has recently been replaced by a third wave of curriculum renewal. ${ }^{1}$

This research was conducted at three facilities that offer Grade R, two of which are in urban areas and one in a rural area. While visiting these facilities, one of the researchers observed that even though some resources were available, these resources were mainly meant as support for teaching numeracy and literacy, with little attention given to science. Since the researcher was a foundation phase student teacher specialising in science education, her interest lay in understanding how science is taught in the early years. As she was aware that the literature on science teaching and learning and teaching in the early years is limited, she was interested in conducting research into the way children understand scientific phenomena in three different contexts. Furthermore, she was also interested in exploring the factors that 
influenced learners' understanding of science in these contexts. The main research question that drove this research was:

How natural science education is understood by teachers and how is this part of the life skills curriculum implemented in the early years?

Subsidiary research questions were:

1. What do children understand about everyday natural science phenomena?

2. What do teachers understand about everyday natural science phenomena?

3. How is the natural science curriculum in the life skills programme implemented in this phase of schooling?

4. What are teachers' views of natural science in this phase of schooling?

The three contexts of the study were a non-government crèche; a Grade R class at a primary school and a Grade R class at a pre-primary school.

\section{Literature review}

Research on early childhood development locally, as well as globally, has focused on policy initiatives in recent years (Mc Cafferty, 2008; Tarner, 2005; Chisholm, 2004; and Biersteker, 2010). However, the factors that impact on the development of children (Biersteker, 2010; Lynch, 2008; Hassink \& Kiiver, 2007; Conezio \& French, 2002) have always been at the centre of much research. One particular aspect of this research focuses on learning during the early years. Researchers in the field of early childhood education generally share certain theoretical assumptions with regard to how young children learn (Conezio \& French, 2002). Examples of such assumptions are that young children learn best from personal experience, rather than from information imparted verbally (French, 1996) and that they construct knowledge through participation with others that foster experimentation, problem solving and social interaction (Gallas, 1995; Chaille \& Britain, 1997). Furthermore, children should be allowed to exercise choice in their learning environment (Bredekamp \& Copple, 1997). Science is an excellent vehicle for developing the above-mentioned skills, including all important social skills.

In the design of the foundation phase natural science curriculum, research with regard to learning in the early years was clearly a guiding force as the RNCS clearly stated that at this level, children are only expected to achieve investigative skills which in essence are 'learning outcome 1' (DoE, 2003). The CAPS document does not refer to investigative skills for Grade R. The learning outcome deals with scientific investigations and children are expected to experiment in their immediate environment. This should be done through series of tasks aimed at all the senses. Such experimental strategies could include looking, listening, smelling, tasting, falling, pulling, pushing, rolling, etc. all of which would help children to become more confident in their own abilities, including an extension of their vocabulary and in doing so, create an interest and a desire to learn (DoE, 2003). 
While the RNCS describes the outcomes related to science learning, as well as what learners should be doing while learning science, there are no guidelines or learning programmes giving teachers clear directions as to the design of the types of activities that would promote science learning. The new NCS as it is discussed in the CAPS, in contrast to the RNCs, includes science concepts, as well as a list of topics to be covered. Like the RNCS it includes a list of basic process skills that learners should acquire. These skills can only be acquired if learners engage in investigative activities. However, guidance as to the types of investigations learners could engage in are also absent. Given that most teachers in the foundation phase, especially those who teach Grade $\mathrm{R}$ in non-governmental institutions, are not science specialists with little or no training in science teaching methodology, how science is taught in the early years is an issue of concern. The RNCS and the CAPS may be progressive documents in the way both envisage science teaching, but have policy makers considered how teachers would respond to this innovative curriculum? This is by no means unique to South Africa, but is a universal problem (Henze, Van Driel \& Verloop, 2007).

While teachers of Grade $\mathrm{R}$ may not require significant 'pedagogic content knowledge $(P C K)$ to teach science concepts, they do require an understanding of the purpose of activities that promote science learning. Too often, because teachers are aware of the fact that science teaching is activity based, teachers design lessons that are activity-driven, rather than guided by the need to understand particular phenomena through an activity (Appleton, 2008). This may be true for any curriculum but the specialisation in science demands a particular type of PCK where teachers are required to progress from understanding 'scientific matte' for themselves, to becoming proficient at elucidating subject matter in ways that are comprehensible to learners (Geddis, 1993; Grossman,1990 \& Shulman,1987).

An aspect that is repeatedly raised by researchers in the field of science education in the early years is the fact that most early childhood education teachers are poorly qualified to teach science (Garett, 2003). The result is teachers who are not confident to teach science as they are aware of their lack of content knowledge (Akerson \& Flaningan, 2000; Smith \& Neale, 1989). While the focus is on investigations in this phase, rather than content knowledge, adequate knowledge of science is necessary to design appropriate science experiences for young children. The ability to ask appropriate and meaningful questions is dependent on a sound understanding of scientific phenomena. Unfortunately this situation often leads to teacher dominated science lessons as this is the only way teachers are able to control events (Garett, 2003). This leaves very little opportunity for learners to interact with the activities and each other. Teachers who believe they do not have sufficient content knowledge to teach science are often wary of teaching science (Sherman \& MacDonald, 2007). Such teachers have to overcome the obstacle of their perception of what it means to teach science at this level. They often have poor experiences with science and/or a general lack of engaging science experiences. This affects their beliefs about what it means to teach science, which are very influential on teachers' abilities to be confident in the teaching of science. This has implications for the pre-service training as well as 
the professional development of teachers: the provision of typical science experiences within the context of pedagogy will help teachers develop an understanding from the perspective of a learner of science and as a teacher of science. Unfortunately, very little attention is paid to the training of teachers with regard to life skills.

Further aspects that may have a profound influence on science teaching and learning in the foundation phase are both physical and social factors (Scholtz, Watson \& Amosun, 2004). Physical factors include class size, books and equipment, while social factors include background of the learners, where they live and the expectations of the community. From the literature review, it is apparent that various factors influence the way a teacher will approach the implementation of the natural science curriculum.

\section{Methodology}

The study is framed by an interpretive paradigm. It is an interpretive study, because we, as researchers, interpreted the data at a particular time, and in a particular context. As interpretive researchers we seek to understand participant's actions and practices in order to describe them in context. We analysed the interviews to see meaning embedded in these texts (De Vos, Strydom, Fouche \& Delport, 2002).

The research approach is an integration of the qualitative and quantitative methods of data collection and analysis. The teacher interviews were analysed qualitatively, while the children's oral questionnaires on how their body works, parts of their body, about plants and animals and their use of science process skills were analysed quantitatively. The research design is that of a case study where the researcher aims to capture the reality of the participants' lived experiences of and thoughts about a particular situation (Cohen, Manion \& Morrison, 2000).

While each context forms a whole unit with boundaries, the fact that the same aspects of the phenomenon under scrutiny is explored in each context, justifies the view that all three localities are regarded as one case. This is referred to by Punch (2009) as a bounded system, emphasising the "unity and wholeness of that system". Researching the three sites as a 'unit' allowed us to obtain a holistic and in-depth understanding of the situations. Various sources of data were used to obtain in-depth information about a particular context, a particular case of learning and teaching of natural science in Grade R (Punch, 2009).

We selected three Grade $\mathrm{R}$ classes in the greater Durban area, two urban and one rural. The rural class, which is referred to as the Green Class in this study, is part of a non-governmental day care centre (crèche), that is situated on the outskirts of the Durban metropolitan area. The first urban class, referred to as the Red Class in the study, is part of a primary school, while the second urban class, referred to as the Blue Class, is part of a pre-primary school. Our choice of schools was based on convenience as we visited the institutions for another project as well. The participants in our study were four teachers from each institution and five children from each class. The children were all in Grade R and were selected randomly from each class. 


\section{Data collection}

Data were collected using two instruments, a questionnaire for children and a semistructured interview for teachers.

\section{Questionnaire}

The children's questionnaire was designed using the RNCS curriculum content as guideline. As children cannot read yet, each question was put to individual participants and their responses duly recorded. Children often responded in their mother tongue and their responses were translated by an isizulu speaking translator. The translator was taken through the questionnaire beforehand and was very familiar with the questions in the instrument.

The RNCS explains what competences learners are expected to achieve by engaging in investigations. While the focus is on investigative skills, the expectation is that learners will acquire knowledge about their immediate environment through investigations. The questions in the questionnaire are based on activities that children would have engaged in previously, and, in the process, have acquired skills and basic knowledge. These activities are as follows:

\section{How their body works}

Children do a number of activities exploring their bodies. They learn to name different parts and engage in activities in which they try to find out what the functions of different parts of their bodies are. This is also linked to Life Orientation. The questionnaire contains five questions based on knowledge children are expected to acquire through exploration.

\section{Your body}

This section also contained five questions. The researcher pointed out certain parts of their bodies on a drawing of the outline of a human being and children were expected to point out where these parts of their bodies are located. The expectation was that children had previously engaged in activities investigating different parts of their bodies and were now able to apply this knowledge.

\section{The environment}

This section contained three questions. One question was about plants and the purpose was to find out to what extent children had engaged with living plants and their life cycles. The second and third questions were about animals and were aimed at determining whether children were able to link structures in animals to structures in humans, demonstrating the skill of distinguishing between similarities and differences.

\section{Descriptions}

The section contained two questions and assessed children's ability to classify and describe. The questions in all four sections were designed to determine whether 
children had developed simple process skills, such as observation, recording, application and classification through active engagement with natural phenomena, i.e. through the investigative process. The data obtained from the questionnaire enabled us to answer the first research question which was: What do children understand about everyday natural science phenomena?

\section{Interviews}

Teachers were interviewed individually and their responses recorded. The questions included in the interview schedule included questions related to teachers' understanding of science in general; the understanding of science in the early years (foundation phase and earlier); the way in which they teach science and how important they think science is. The data obtained from the interviews enabled us to answer the remaining three research questions: What do teachers understand about everyday natural science phenomena? How is the natural science curriculum implemented in this phase of schooling? What are teachers' views of natural science in this phase of schooling?

The interviews and questionnaire are fit for the purpose as they were designed with the research questions in mind. All data collected served the purpose of answering the research questions. A limitation of the study may be the fact that little triangulation occurred as the two different instruments produced different data and answered different questions. The fact that children and teachers were interviewed individually ensured that they were not influenced by each other.

\section{Results}

The findings are reported in two parts: Firstly, children's responses to the questionnaire and secondly teachers' responses to the interview questions. Although the questionnaire was divided into four main questions, the results are reported in three parts as the results for the first two sections are reported together. The reason for this is that the questions cover the same topic. Part one deals with the question relating to what children think are in their bodies; part two deals with the environment and part three deals with classification and description. The results from all three sections serve to answer the first research question. Table 1 presents the results for the first part of the questionnaire.

Table 1: Children's interpretation of what is in their bodies.

\begin{tabular}{|c|c|c|}
\hline \multicolumn{3}{|c|}{ Average percentage for each group } \\
\hline Green Class & Red Class & Blue Class \\
\hline 59,2 & 78,4 & 86,9 \\
\hline
\end{tabular}

The results show that children from Green Class have some understanding of the functioning of their bodies and the ability to link parts of their bodies, observed in pictures, to their own bodies, while children from Red and Blue Classes have a very good understanding of both phenomena. The second part presents results on 
children's understanding of phenomena in the environment and the events occurring around them. Table 2 presents the results.

Table 2: Children's understanding of environmental phenomena.

\begin{tabular}{|c|c|c|}
\hline \multicolumn{3}{|c|}{ Average percentage for each group } \\
\hline Green Class & Red Class & Blue Class \\
\hline 83,6 & 98,1 & 90,9 \\
\hline
\end{tabular}

Children in all three locations have a very good understanding of the basic life processes of plants, as well as the ability to describe similarities and differences. However, the children from Green Class did not perform as well as children from the other two facilities. The third part presents the results of children's ability to classify and describe phenomena. Table 3 presents the results.

Table 3: Children's ability to classify and describe.

\begin{tabular}{|c|c|c|}
\hline \multicolumn{3}{|c|}{ Average percentage for each group } \\
\hline Green Class & Red Class & Blue Class \\
\hline 63,3 & 80,0 & 73,3 \\
\hline
\end{tabular}

The total performance for each group is presented in Table 4.

Table 4: Average performance for all questions.

\begin{tabular}{|c|c|c|}
\hline \multicolumn{3}{|c|}{ Total average percentage for each group } \\
\hline Green Class & Red Class & Blue Class \\
\hline 66,0 & 83,7 & 86,5 \\
\hline
\end{tabular}

The results obtained for the children's questionnaire answers the first research question in that it reveals the understanding of children with regard to natural phenomena. The question arises as to why the children from Green Class did not perform as well as children from the other two classes. This rural crèche is more isolated than the two urban schools and that it depends on funding for its operation, the teachers are sent for basic early childhood training and invariably are less qualified in the sense that their understanding of science is poorer than those from urban areas. The urban schools are also better resourced than the rural crèche, pointing to the importance of adequate resources for schools. As the research has shown, teachers who are poorly qualified to teach science often neglect to teach it in a way that assists in the development of process skills. This may be the case with the teachers of the Green Class in this study.

The second phase of the research focused on teachers' understanding of certain science concepts, the importance they place on science, as well as the way they teach science. In observing the teachers teaching science the use of investigative methods was the main focus. This was important as it is one of the outcomes of the curriculum 
where learners are expected to develop and use process skills. The teachers from the crèche opted to use electricity to support their statements. Apparently electricity is a topic often discussed. Table 5 presents the results for the teachers teaching at the rural crèche.

Table 5: Teachers responses (crèche).

\begin{tabular}{|c|c|c|c|c|}
\hline \multicolumn{5}{|c|}{ Crèche } \\
\hline Questions & Teacher A & Teacher B & Teacher C & Teacher D \\
\hline $\begin{array}{l}\text { What is your } \\
\text { understanding of } \\
\text { science? } \\
\text { (electricity) }\end{array}$ & $\begin{array}{l}\text { Working with } \\
\text { electricity }\end{array}$ & Electricity & $\begin{array}{l}\text { Talk about } \\
\text { electricity, } \\
\text { wear shoes, } \\
\text { call electrician, } \\
\text { children must } \\
\text { stay away. } \\
\text { Electricity must } \\
\text { stay off the } \\
\text { ground (e.g. } \\
\text { ovens). }\end{array}$ & $\begin{array}{l}\text { Hard to learn, } \\
\text { calculations, } \\
\text { dangerous. }\end{array}$ \\
\hline $\begin{array}{l}\text { What is your } \\
\text { understanding } \\
\text { of science in the } \\
\text { ECD phase? }\end{array}$ & Yes, cleaning & $\begin{array}{l}\text { Yes, explaining } \\
\text { about electricity } \\
\text { and dangers. }\end{array}$ & $\begin{array}{l}\text { Talk about } \\
\text { electricity, } \\
\text { wear shoes, } \\
\text { call electrician, } \\
\text { children must } \\
\text { stay away. } \\
\text { Electricity must } \\
\text { stay off the } \\
\text { ground (e.g. } \\
\text { ovens). }\end{array}$ & - \\
\hline $\begin{array}{l}\text { Is science } \\
\text { education } \\
\text { important to } \\
\text { young children? } \\
\text { Why/why not? }\end{array}$ & Yes & $\begin{array}{l}\text { Yes, they know it } \\
\text { is dangerous. }\end{array}$ & $\begin{array}{l}\text { Yes, people must } \\
\text { be taught about } \\
\text { dangers. }\end{array}$ & Yes \\
\hline $\begin{array}{l}\text { Do you integrate } \\
\text { science } \\
\text { education into } \\
\text { the curriculum? } \\
\text { If so indicate: } \\
\text { Time spent. }\end{array}$ & Yes & Yes & - & - \\
\hline $\begin{array}{l}\text { How often a } \\
\text { week? }\end{array}$ & Once a day & Once a week & - & - \\
\hline
\end{tabular}




\begin{tabular}{|l|l|l|l|l|}
\hline \multicolumn{4}{|c|}{ Crèche } \\
\hline \multicolumn{1}{|c|}{ Questions } & \multicolumn{1}{|c|}{ Teacher $\mathbf{A}$} & \multicolumn{1}{c|}{ Teacher $\mathbf{B}$} & Teacher C & \multicolumn{1}{c|}{ Teacher D } \\
\hline $\begin{array}{l}\text { Example of } \\
\text { activities done }\end{array}$ & Wind mills & Wind mills & Pollution art & Wind mills \\
\hline
\end{tabular}

The results show that teachers are still very much inclined to control the learning environment by telling children what they ought to know. There is no indication that any of the four teachers planned investigative activities with regard to learning about electricity. There is also evidence of teachers' misconceptions in the way they describe electricity (Teacher C). There is no evidence that teachers implement a process approach by planning investigative activities for children in this phase. Their focus is on telling children what they need to know. Their views of the importance of science education support the view that they see science as a body of knowledge that needs to be transmitted. Teachers could not say how much time they spent on science lessons, although two teachers were able to indicate that they taught science once a week. Examples of activities mentioned by all teachers are not investigative by nature. Table 6 presents the views of teachers form the Grade R classes in the primary school.

Table 6: Teachers responses (primary school).

\begin{tabular}{|c|c|c|c|c|}
\hline \multicolumn{5}{|c|}{ Grade $\mathrm{R}$ teachers at a primary school } \\
\hline Questions & Teacher A & Teacher B & Teacher C & Teacher D \\
\hline $\begin{array}{l}\text { What is your } \\
\text { understanding of } \\
\text { science? }\end{array}$ & $\begin{array}{l}\text { Experiments, } \\
\text { working out } \\
\text { answers; } \\
\text { measurements, } \\
\text { hard methodical- } \\
\text { (formulas) things } \\
\text { to follow. }\end{array}$ & $\begin{array}{l}\text { Experiments, } \\
\text { different } \\
\text { aspects of the } \\
\text { environment. }\end{array}$ & $\begin{array}{l}\text { The world and } \\
\text { how it works, } \\
\text { finer details. }\end{array}$ & $\begin{array}{l}\text { Laboratories, } \\
\text { green smoke, } \\
\text { stuff, medication, } \\
\text { research. }\end{array}$ \\
\hline $\begin{array}{l}\text { What is your } \\
\text { understanding } \\
\text { of science in the } \\
\text { ECD Phase? }\end{array}$ & $\begin{array}{l}\text { More } \\
\text { mathematical } \\
\text { than science, } \\
\text { integrated } \\
\text { through other } \\
\text { subjects (e.g. } \\
\text { movement) } \\
\text { incidental } \\
\text { learning, working } \\
\text { with concrete } \\
\text { objects, all } \\
\text { to increase } \\
\text { vocabulary. }\end{array}$ & $\begin{array}{l}\text { Experiments } \\
\text { of different } \\
\text { topics, hands } \\
\text { on, incidental } \\
\text { learning. }\end{array}$ & $\begin{array}{l}\text { Finding out why } \\
\text { things happen, } \\
\text { incidental. }\end{array}$ & $\begin{array}{l}\text { Experimental, } \\
\text { practical }\end{array}$ \\
\hline
\end{tabular}




\begin{tabular}{|c|c|c|c|c|}
\hline \multicolumn{5}{|c|}{ Grade $\mathrm{R}$ teachers at a primary school } \\
\hline Questions & Teacher A & Teacher B & Teacher C & Teacher D \\
\hline $\begin{array}{l}\text { Is science } \\
\text { education } \\
\text { important to } \\
\text { young children? } \\
\text { Why/why not? } \\
\end{array}$ & $\begin{array}{l}\text { Yes, for them to } \\
\text { see, touch. }\end{array}$ & $\begin{array}{l}\text { Yes, very, need } \\
\text { to know why } \\
\text { things happen } \\
\text { and how to look } \\
\text { after it. } \\
\end{array}$ & Yes & $\begin{array}{l}\text { Yes, for the full } \\
\text { development of } \\
\text { the child. }\end{array}$ \\
\hline $\begin{array}{l}\text { Do you integrate } \\
\text { science } \\
\text { education into } \\
\text { the curriculum? } \\
\text { If so indicate: } \\
\text { Time spent. }\end{array}$ & 15-20 minutes & 15-20 minutes & - & - \\
\hline $\begin{array}{l}\text { How often a } \\
\text { week? }\end{array}$ & Once & $\begin{array}{l}\text { Once a week - } \\
\text { discussion }\end{array}$ & - & - \\
\hline $\begin{array}{l}\text { Example of } \\
\text { activities done }\end{array}$ & Show and tell & $\begin{array}{l}\text { Discussion of the } \\
\text { moon, incidental } \\
\text { learning. }\end{array}$ & $\begin{array}{l}\text { Discussion, show } \\
\text { and tell, looking } \\
\text { at books, garden } \\
\text { work, lots of } \\
\text { posters. }\end{array}$ & Discussion \\
\hline
\end{tabular}

Teachers' responses with regard to their understanding of science reveal some understanding of the nature of science. They are more aware than the teachers from the rural crèche that science is more a process than a product, although some misconceptions are still evident. They have a better sense of the integrative nature of life skills, as well as the fact that the essence of the approach to science in the early years should be an exploration of natural phenomena. These teachers were better able to articulate their views of the importance of science to children, in this phase, by explaining the value of science education. Two of the teachers were also quite specific about the time spent on science. Examples of activities conducted give some indication of understanding the investigative nature of science, although there is still a strong emphasis on discussion rather than action. Table 7 presents the views of teachers form the Grade R classes in the pre-primary school. 
Table 7: Teachers responses (pre-primary school).

\begin{tabular}{|c|c|c|c|c|}
\hline \multicolumn{5}{|c|}{ Grade $\mathrm{R}$ teachers at a pre-primary school } \\
\hline Questions & Teacher A & Teacher B & Teacher C & Teacher D \\
\hline $\begin{array}{l}\text { What is your } \\
\text { understanding } \\
\text { of science? }\end{array}$ & $\begin{array}{l}\text { Finding an } \\
\text { answer to a } \\
\text { question. }\end{array}$ & $\begin{array}{l}\text { Natural, } \\
\text { physical }\end{array}$ & $\begin{array}{l}\text { How things } \\
\text { work, how } \\
\text { things come } \\
\text { together, } \\
\text { process. }\end{array}$ & $\begin{array}{l}\text { Way things } \\
\text { work - } \\
\text { weather, } \\
\text { environment, } \\
\text { chemicals, } \\
\text { experiments- } \\
\text { how things } \\
\text { react. }\end{array}$ \\
\hline $\begin{array}{l}\text { What is your } \\
\text { understanding } \\
\text { of science in } \\
\text { the ECD phase? }\end{array}$ & $\begin{array}{l}\text { Exploring with } \\
\text { experiments, } \\
\text { measuring, } \\
\text { different } \\
\text { capacities, } \\
\text { obtaining a } \\
\text { certain result, } \\
\text { do experiment, } \\
\text { see if what you } \\
\text { thought was } \\
\text { correct, natural } \\
\text { science around } \\
\text { the world (e.g. } \\
\text { plant growing). }\end{array}$ & $\begin{array}{l}\text { Nature -things } \\
\text { that are not } \\
\text { man-made. } \\
\text { (God made } \\
\text { them) } \\
\text { Own bodies- } \\
\text { how to look } \\
\text { after it, } \\
\text { understanding } \\
\text { of and how it } \\
\text { works. }\end{array}$ & $\begin{array}{l}\text { Environmental } \\
\text { (own } \\
\text { environment) } \\
\text { Close to } \\
\text { home and } \\
\text { themselves. }\end{array}$ & $\begin{array}{l}\text { How things } \\
\text { work, what you } \\
\text { need to survive, } \\
\text { movement. }\end{array}$ \\
\hline $\begin{array}{l}\text { Is science } \\
\text { education } \\
\text { important to } \\
\text { young children? } \\
\text { Why/why not? }\end{array}$ & $\begin{array}{l}\text { Yes, from a } \\
\text { young age } \\
\text { they need to } \\
\text { know what } \\
\text { is happening } \\
\text { around them. } \\
\text { It created } \\
\text { foundations. }\end{array}$ & $\begin{array}{l}\text { Yes, science you } \\
\text { see every day- } \\
\text { learning allows } \\
\text { you to think } \\
\text { about it, more } \\
\text { understanding } \\
\text { of your } \\
\text { surroundings. }\end{array}$ & $\begin{array}{l}\text { Yes, very, } \\
\text { should know } \\
\text { why things are } \\
\text { there, how they } \\
\text { got there, how } \\
\text { they work. To } \\
\text { be creative and } \\
\text { inventive. }\end{array}$ & $\begin{array}{l}\text { Yes, the basics- } \\
\text { so they can } \\
\text { apply basic } \\
\text { knowledge } \\
\text { later on in life. }\end{array}$ \\
\hline $\begin{array}{l}\text { Do you } \\
\text { integrate } \\
\text { science } \\
\text { education into } \\
\text { the curriculum? } \\
\text { If so indicate: } \\
\text { Time spent. }\end{array}$ & 3ominutes & $\begin{array}{l}10 \text { min } \\
\text { (discussion) } \\
30 \text { minutes } \\
\text { (Activities) }\end{array}$ & 30 minutes & 15-30 minutes) \\
\hline
\end{tabular}




\begin{tabular}{|c|c|c|c|c|}
\hline \multicolumn{5}{|c|}{ Grade $\mathrm{R}$ teachers at a pre-primary school } \\
\hline Questions & Teacher A & Teacher B & Teacher C & Teacher D \\
\hline $\begin{array}{l}\text { How often a } \\
\text { week? }\end{array}$ & Once & Everyday & $\begin{array}{l}\text { One allotted } \\
\text { time, but } \\
\text { basically } \\
\text { everyday. }\end{array}$ & Everyday \\
\hline $\begin{array}{l}\text { Example of } \\
\text { activities done }\end{array}$ & $\begin{array}{l}\text { Growing plants, } \\
\text { experiments on } \\
\text { movement }\end{array}$ & $\begin{array}{l}\text { Discussion } \\
\text { about weather, } \\
\text { body, doing a } \\
\text { nature collage } \\
\text { using seeds, } \\
\text { leaves, stories. }\end{array}$ & $\begin{array}{l}\text { Exploration } \\
\text { tables (put } \\
\text { something } \\
\text { different on } \\
\text { each table) } \\
\text { games as a } \\
\text { follow-up } \\
\text { activity, using } \\
\text { real objects. }\end{array}$ & Growing plants \\
\hline
\end{tabular}

Teachers at this school, like their colleagues from the primary school, have some idea of the nature of science. There is evidence of understanding that science is a process of investigation and discovery. In answering the question with regard to science in the early years, it was evident that teachers had experience of investigative activities as well as the skill of integrating science with other learning areas. Their views of the importance of science in the early years also confirm some understanding of the nature of science. Three of the four teachers at this school also spend considerable time integrating science in their teaching of language and numeracy. Their examples of activities in science show that two of the teachers employ some aspects of an investigative approach.

\section{Discussion and conclusion}

The results show that the urban schools scored higher than the rural crèche. There may be a number of reasons for this, but the most obvious reason is most likely a lack of resources, including human resources. While data were not collected on teachers' qualifications, observing the teachers in action indicated that the teachers at the crèche were not as skilled in teaching science as the teachers from the urban schools (Geddis, 1993; Grossman, 1990). Another factor that could have impacted on learners results is the fact that children from the rural crèche are not as conversant in English as those from the urban schools. However, the fact that a translator was at hand to translate children's responses should not have had a significant effect. Children from the crèche scored poorly in the section on the functions of different parts of the body. This may be due to the fact that children in the Grade $R$ class were on average younger than those from urban schools, and they may not have been developmentally ready for this kind of activity. Integrating this section with Life Orientation and specifically healthy living should enhance learning of this topic, but if teachers do not have the skill 
to integrate, and plan for active learning, learners may not be able to progress from naming structures to understanding their purpose (Lynch, 2008).

All three groups scored reasonably high in the section on the environment. This may be due to the fact that the questions were more related to their everyday experiences than other questions as most children were familiar with most of the animals in the pictures. Furthermore, the fact that pictures were used to prompt responses meant that language was not as central to the answers as the other questions.

The scores for section three were also fairly high (all scored above 80\%), although the Green Class had the lowest score of the three. As this section required children to describe objects, language was an important factor and those children who were not as proficient in their mother tongue, struggled to explain what was observed. In conclusion, it can be said that this research showed that children from three different Grade $\mathrm{R}$ contexts had a reasonable understanding of natural science phenomena, with children from the rural crèche having a poorer understanding than children from urban crèches. Whether this understanding is due to their engagement in investigative activities or simply from discussion in class, is difficult to determine, although there is some indication that children have acquired basic process skills, which point to some level of investigative activities.

With regard to teachers' understanding of science and specifically their understanding of science education in the early years, there appears to be significant differences between teachers from the rural crèche and those from the urban schools. Teachers from the primary and pre-primary schools have a better understanding of how to implement the curriculum, while the teachers from the rural crèche have a poor understanding of the curriculum. Casual observation of the teachers from the two schools indicated a mismatch between what they say and what they do. They appear to have learnt the discourse of investigative science, without really implementing it as often as the curriculum requires. There is more emphasis on discussion than on activity based learning. While all teachers indicated that they thought it was important to learn science, teachers for the rural crèche could not articulate why they said so.

The question does arise as to why children from the pre-primary school had the highest overall score of the three schools. The reason for this may be that this is a preschool that focuses only on ECD and the ethos is very much one of learning through doing (Gallas, 1995; Chaille \& Britain, 1997). While the facilities and the teacher's qualifications are on a par with the pre-primary school, the Red Class is part of a primary school and there is more emphasis on preparing children for formal schooling than on allowing them to learn by exploring, and this may account for the lower score. The Green Class is at a disadvantage with regard to funding and with regards to the qualifications of its teachers.

The finding of this study raises the issue of the necessity for the National Department of Education to take responsibility for early childhood education nationally. While crèches like the one which participated in this study are doing the best they can under financial and other constraints, we still have the situation of 
under-qualified teachers teaching in the foundation phase. Teachers in such facilities are also given very little support in developing the skills to implement the curriculum. While it is the policy of the DoE to include Grade $R$ in the foundation phase in the primary school, teachers who teach Grade $\mathrm{R}$ in these schools may do well to interact more closely with teachers who teach at pre-primary schools that focus exclusively on early childhood education. Such interaction may assist them in planning more activities with an investigative approach. In conclusion while there is strong evidence to suggest that teacher qualifications are crucial in teaching science through investigation, it also depends on how schools and particularly teachers, view science teaching.

\section{Endnote}

1. With the implementation of the new NCS, the Curriculum and Assessment Policy Statement (CAPS) replaces Subject Statements, Learning Programme Guidelines and Subject Assessment Guidelines in an effort to improve implementation. However, the CAPS still places emphasis on the process of enquiry which involves the development of science process skills. This research is therefore still relevant in spite of policy document changes.

\section{References}

Akerson, V. L. \& Flaningan, J. (2000). Preparing pre-service teachers to use an interdisciplinary approach to science and language arts instruction. Journal of Science Teacher Education, 11: 287-313.

Appleton, K. (2008). Developing science pedagogical content knowledge through mentoring elementary teachers. Journal of Science Teacher Education, 19: 523-545.

Biersteker, L. (2010). How ready are our children for Grade R? [Online.] Available from: http://www.cepd.org.za/files/pictures/Final\%20Report-April\%20201\%CEPD. (Accessed 12 June 2012.)

Bredekamp, S. \& Copple, C. (eds.) (1997). Developmentally appropriate practice in early childhood programmes. Washington DC: National Association for the Education of Young Children.

Chaillè, C. \& Britain, L. (1997). The young child as scientist: A constructivist approach to early childhood science education. New York: Longman.

Chisholm, L. (2004).Changing Class: Education and social change in post-apartheid South Africa. Cape Town: HSRC Press.

Cohen, L., Manion, L. \& Morrison, K. (2000). Research methods in education. London: Routledge Falmer.

Conezio, K. \& French, L. (2002). Science in the preschool classroom: Capitalising on children's fascination with the everyday world to foster language and literacy development. Young Children, September, 2002. [Online.] Available from: http:// www.journal.naeyc.org/btj/200209/SciencelnThePreschoolClassroom.pdf (Accessed 10 September 2008.) 
Constitution of South Africa. (1996) Constitution of the Republic of South Africa, No. 108 of 1996. Statutes of the Republic of South Africa. Pretoria: Government Press.

Department of Education (DoE). (2010). Education for All (EFA). 2009 Country Report: South Africa. Pretoria: Department of Basic Education.

Department of Education (DoE). (2003). Revised National Curriculum Statement, Grade R-9 (Schools) Policy. Teacher's guide for the development of learning programmes, foundation phase. Pretoria: Government Press.

Department of Education (DoE). (2001). Education White Paper 5 on Early Childhood Education. Meeting the challenge of Early Childhood Development in South Africa. Pretoria: Government Press.

Department of Education (DoE). (1996). National Education Policy Act No. 27 of 1996. Admission policy for ordinary public schools. Government Gazette 400(19377). Pretoria: Government Press.

De Vos, A.S., Strydom, H. \& Delport, C.S.L. (2002). Research at Grassroots for the social sciences ( $2^{\text {nd }}$ ed.). Pretoria: Van Schaik Publishers.

French, L. (1996). Science as the centre of a coherent, integrated early childhood curriculum. Early Childhood Research Quarterly, 19(1): 138-149.

Gallas, K. (1995). Talking their way into science: Hearing children's questions and theories, responding with curricula. New York: Teachers College Press.

Garett, D. (2003). Science education in early childhood teacher education: Putting forward a case to enhance student teachers' confidence and competence. Research in Science Education, 33: 467-481.

Geddis, A. N., Onslow, B., Beynon, C. \& Oesch, J. (1993). Transforming content knowledge: Learning to teach about isotopes. Science Education, 77(6): 575-591.

Grossman, P. L. (1990). The making of a teacher: Teacher knowledge and teacher education. New York: Teachers College Press.

Hassink, W. \& Kiiver, H. (2007). Age-dependent effects on socio-economic. [Online.] Available from: http://www.koopmaninstitute.uu.nl. (Accessed 22 October 2008.)

Henze, I., Van Driel, J. H. \& Verloop, N. (2007). Science teachers' knowledge about teaching models and modelling in the context of a new syllabus on public understanding of science. Research in Science Education, 37: 99-122.

Lynch, J. ( 2008). Engagement with print: Low-income families and head start children. Journal of Early Childhood Literacy, 8(2): 151-175.

Mc Cafferty, R. (2008). National Curriculum Statement has been finalised. [Online.] Availablefrom:http://www.christainaction.org.newsletter_uca/uca-artic_national curriculum.htm. (Accessed 29 September 2008.)

McMillan, J. H. \& Schumacher, S. (2001). Research in education: a conceptual introduction. New York: Longman.

Punch, K. F. (2009). Introduction to research methods in education. London: Sage. 
Scholtz, Z., Watson, R. \& Amosun, O. (2004). Investigating science teachers' response to curriculum innovation. African Journal of Research in Science, Mathematics and Technology Education, 8(1): 41-52.

Sherman, A. \& MacDonald, L. (2007). Pre-service teachers' experiences with a science education module. Journal of Science Teacher Education, 18: 525-541.

Shulman, L. (1987). Knowledge and teaching: Foundations of the new reform. Harvard Education Review, 57(1): 1-22.

Smith D. C. \& Neale, D. C. (1989). The construction of subject matter knowledge in primary science teaching. Teaching and teacher education, 5(1): 1-20.

Tamer, M. (2005). A long way to go: Forum on South Africa's education system highlights post-apartheid pitfalls and progress. [Online.] Available from: http:// www.gse.harvard.edu/news_events/features/2005/09/southafrica0901.html. (Accessed 29 September 2008.)

United Nations Committee on Education. (1990). Plan of action for implementing the world declaration on the survival, protection and development of children in the 1990's. USA: UNICEF. 